\title{
MORPHOLOGICAL CHARACTERISTICS OF LOCAL POPULATIONS OF EUROPEAN VENDACE Coregonus albula (L.) IN SOME LAKES OF LATVIA DURING 50 YEARS
}

\author{
Jeḷena Oreha and Natalja Škute \\ Institute of Ecology, Daugavpils University, Vienības iela 13, Daugavpils, LV-5401, LATVIA; \\ e-mail: jelena.oreha@du.Iv, natalja.skute@du.Iv
}

Communicated by İzaks Rašals

\begin{abstract}
The vendace (Coregonus albula (L.)) is a widespread fish in the waters of the Holarctic and has been much studied in regard to history of spread and evolution. Statistical analysis of morphometric and meristic changes in Coregonus albula in some Latvian lakes for the last 50 years was conducted. Cluster analysis of meristic parameters showed that the vendace populations of lakes Stirnu - Alūksnes have become closer in meristic properties while the vendace populations of lakes Drïdzis - Sventes have become more dissimilar. The diversity and variation of morphological characteristics of vendace in the studied lakes are within the range of variations of the European vendace (Coregonus albula), although due to its flexibility it makes a lake-specific form depending on the local conditions of each reservoir. The discovered differences in the vendace populations from Lakes Nirzas, Rāznas, Stirnu, Alūksnes, Drïdzis, and Sventes seem to have resulted solely from/due to the adaptation of vendace to living conditions, which has changed during the previous 50 years.
\end{abstract}

Key words: Coregonus albula, morphometric and meristic characteristics, adaptation, environmental conditions.

\section{INTRODUCTION}

Fishes of the Coregonidae species have been studied regarding their taxonomy and history of spread: the current structure of this group has undergone a relatively recent development, i.e. in the end of the Tertiary - beginning of the Quaternary period, and it exhibits exceptionally high morphological and ecological variation (Решетников, 1980).

The vendace (Coregonus albula) is a widespread fish in the waters of the Holarctic, and reached North-Western Europe after glaciations. The vendace exhibits great variation in morphological characteristics, also, in the sub-species level.

Vendace is a representative of the genus Salmo, order Salmoniformes, family Salmonidae, sub-family Coregoninae, species Coregonus albula. It is a lake fish that feeds on plankton. Spawning requires a clean gravel bed. At the beginning of the last century, Coregonus albula was artificially introduced from the Lakes Peipus and Ladoga to more than 30 Latvian lakes. Industrial catch of vendace in the 1930s reached 13 tonnes from one lake. In 1990, vendace was registered only in five lakes (Plikšs un Aleksejevs, 1998). Presently it can be found in many Latvian lakes, however, its share in the fishery is not big; the catch is insignificant and unstable. This species is included in the list of specially protected species with limited use in Latvia
(Regulation No. 396 of the Cabinet of Ministers of the Republic of Latvia, 14 November 2000).

Morphological characteristics of Latvian vendace were last investigated in the 1950s-1960s (Laganovska, 1957; Никаноров, 1964).

Given the high degree of variability of vendace and taking into account the fact that it belongs to economically valuable marketable fishes, it seems of interest to determine the changes in the populations of Coregonus albula that have occurred since the last studies of the mid-twentieth century, by means of morphometric investigations, as well as to determine the major factors that led to these changes, present a scientific interest. Lack of precise scientific data regarding the local vendace populations and its biology hinders a rational exploitation of this fish and does not allow opportunities of its introduction in Latvian lakes. The aim of present research was to analyse meristic properties and morphological features changes of Coregonus albula for the last 50 years in Latvian lakes.

\section{MATERIALS AND METHODS}

Study sites and sample collection. Vendace samples, in total 198 individuals, were collected from six Latvian lakes, namely, lakes Alūksnes, Stirnu, Nirzas, Drīdzis, Rāznas and 


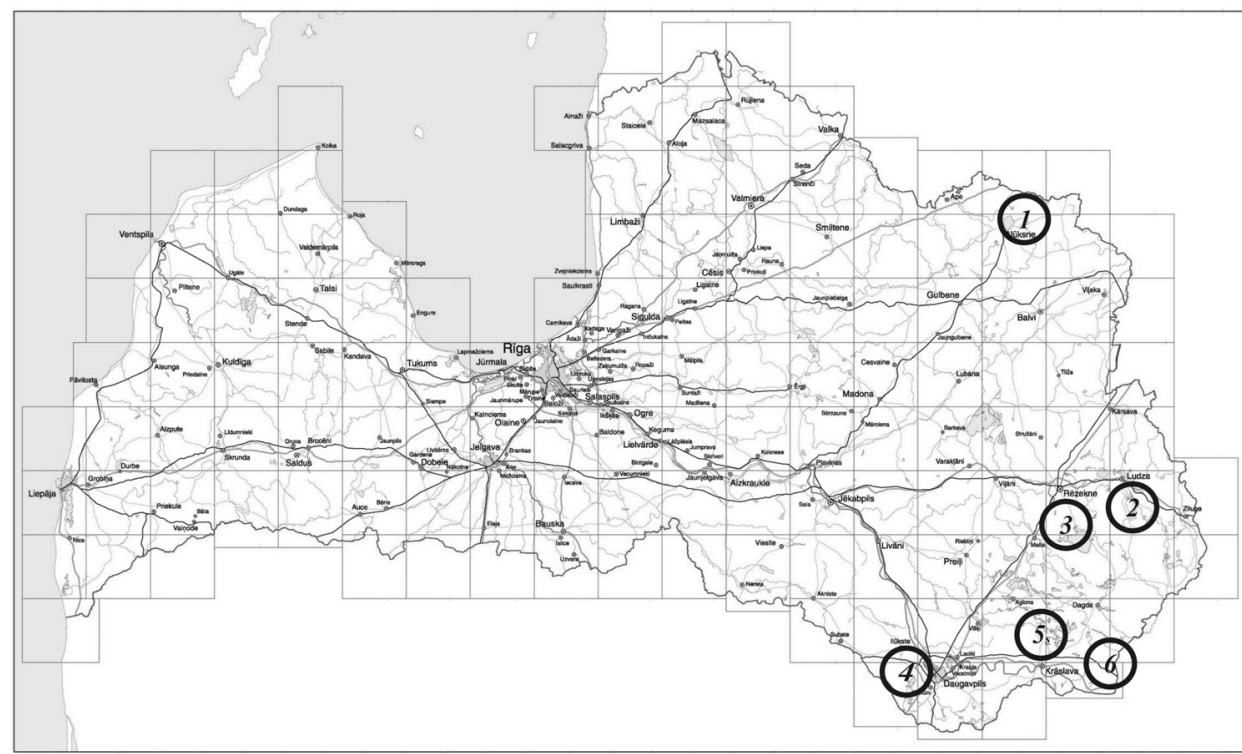

Table 1
Fig. 1. Location of the investigated lakes in Latvia where vendace were sampled (1 Lake Alūksnes, 2 - Lake Nirzas, 3 - Lake Rāznas, 4 - Lake Sventes, 5 - Lake Drīdzis, 6 - Lake Stirnu).

T a b le 2

MORPHOLOGICAL CHARACTERISTICS OF SIX LAKES WHERE VENDACE WERE SAMPLED ${ }^{1}$

\begin{tabular}{|c|c|c|c|c|}
\hline \multirow[t]{2}{*}{ Lake } & \multirow[t]{2}{*}{ Location } & \multirow[t]{2}{*}{ Area } & \multicolumn{2}{|c|}{ Depth } \\
\hline & & & $\max$ & average \\
\hline Drīdzis & $\begin{array}{l}\text { Skaista and Kombuḷi rural munici- } \\
\text { palities, Krāslava District }\end{array}$ & 753.2 ha & $65.1 \mathrm{~m}$ & $12.8 \mathrm{~m}$ \\
\hline Rāznas & $\begin{array}{l}\text { Kaunata, Mākoņkalns and Čornaja } \\
\text { rural municipalities, Rēzekne Dis- } \\
\text { trict }\end{array}$ & 5756.4 ha & $17.0 \mathrm{~m}$ & $7.0 \mathrm{~m}$ \\
\hline Alūksnes & $\begin{array}{l}\text { Jaunalūksne, Alūksne, Mārkalne } \\
\text { and Ziemera rural municipalities, } \\
\text { Alūksne District }\end{array}$ & $1,543.7 \mathrm{ha}$ & $15.2 \mathrm{~m}$ & $7.1 \mathrm{~m}$ \\
\hline Nirzas & $\begin{array}{l}\text { Nirza rural municipalities, Ludza } \\
\text { District }\end{array}$ & 552 ha & $21 \mathrm{~m}$ & $8.2 \mathrm{~m}$ \\
\hline Stirnu & $\begin{array}{l}\text { Kalniešu rural municipalities, } \\
\text { Krāslava District }\end{array}$ & 148 ha & $25.8 \mathrm{~m}$ & $7.7 \mathrm{~m}$ \\
\hline Svente & $\begin{array}{l}\text { Svente rural municipalities, } \\
\text { Daugavpils District }\end{array}$ & 734.8 ha & $38 \mathrm{~m}$ & $7.8 \mathrm{~m}$ \\
\hline
\end{tabular}

Sventes (see the description of lakes in Table 1, and their location in Fig. 1). The studied fish species is a very rare one which makes it impossible to collect a big sample of individuals although a morphological analysis of the fish presents interest. Due to the current global tendency of lowering species diversity it seems possible to carry out analysis of a rare fish species using a smaller sample (Lowe $e t$ al., 2004).

Freshly caught vendace individuals were measured by whitefish measurement methods described bу Правдин (1966) and commonly used today (Lajus, 2001; Перескоков и Рогозин 2001; Lajus, 2003; Kaupinis and Bukelskis, 2004; Гуричев и Белоусов, 2005). The measured morphological features are presented in Table 2; the lateral view of vendace indicating points used for morphometric measurement are shown in Figure 2. Plastic (morphometric) properties are presented as measurement indices expressed in per cent of the head length.
MEASURED MORPHOLOGICAL FEATURES OF VENDACE

\begin{tabular}{c|c}
$\begin{array}{c}\text { Abbre- } \\
\text { viation }\end{array}$ & Description of morphological features \\
\hline \multicolumn{2}{c}{ Morphometric features }
\end{tabular}

HL Head length: from the snout end to the farthest gill cover edge

ED Horizontal diameter of the eye: from the anterior to the posterior edge of the eye

PO Postorbital length: from the posterior edge of the orbit to the farthest gill cover edge

StL Snout length: from the snout end to the anterior edge of the eye

Meristic features

LL Number of the perforated scales on the lateral line

Sp.br. Number of gill rakers on the first left gill arch

RA Number of ray in anal fin

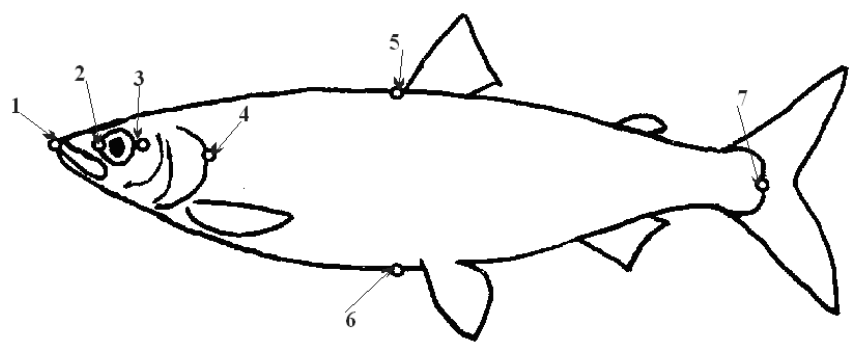

Fig. 2. Lateral view of vendace indicating landmarks used for morphometric measurements

$1-2$, snout length (StL); 2 - 3, horizontal diameter of the eye (ED); 3 - 4, postorbital length (PO); $1-4$, head length (HL); $5-6$, body depth (H); 1 7, fish length (SL); $4-7$, body length (OD).

Statistical analysis. In order to evaluate variation morphometric parameters of Coregonus albula that have taken place during the last 50 years, our data was compared to that collected from lakes Drīdzis, Stirnu, Alūksnes and Rāznas (Laganovska, 1957), and from lakes Nirzas and Sventes (Никаноров, 1964). Head measurement indices (snout length, eye diameter, and postorbital length in relation to the head length) of the vendace individuals in lakes 
Drīdzis, Stirnu, Alūksne, and Nirza were compared. Mean values of indices of the above mentioned parameters were considered for each lake separately. The Student criterion for unequal samples was used (Лакин, 1980; Arhipova and Bālina, 2003) to determine significant differences. The difference between samples was considered to be significant when $P<0.01$ according to Pravdin (Правдин, 1966) and Reshetnikov (Решетников, 1980).

On the basis of morphometric data, fish condition was examined for each individual separately, and the average condition for each population was estimated. The fish condition was calculated as the Fulton condition factor $(\mathrm{K}) K=\frac{w \times 100}{L^{3}}$, where $w$ is the fish weight in grams, and $L$ the fish length from the snout end to the end of scales layer at the caudal fin base (Правдин, 1966).

Since body measurement indices depend on age, Coregonus spp. sexually mature individuals aged $3+$ were used for the analysis of plastic properties. Age was determined according to Pravdin (Правдин, 1966). Sexual dimorphism in the Coregonus spp. appears only during spawning. Thus, in order to test for significant differences, distinctions in the morphological parameters of males and females aged 3+, using Single Factor analysis (ANOVA) were determined.

To determine the meristic properties of Coregonus albula in Latvian lakes on age and gender, Two-Factor analysis Without Replication (ANOVA) $(P<0.05)$ was carried out. No dependence of meristic properties on age and gender was discovered. Proceeding from this, meristic parameter indices were calculated and pooled in samples from each lake.

Hierarchical cluster analysis based on three meristic properties (number of rays in anal fin (RA), number of scales in the lateral line (LL), number of gill rakers on the gill arch (sp.br)) was carried out, and a dendrogramme was produced to determine similarity between populations. The means of variables were standardised by the z-scores function, Euclidian distances were calculated for pairs of populations, and the populations were combined by stepwise clustering using the UPGMA method (unweighted pair-group method using arithmetic averages). The cluster analysis was conducted based on data obtained by the authors in 2007, as well as on the data presented by Laganovska (1957) and Nikanorov (Никаноров, 1964).

\section{RESULTS}

Morphometric properties. Head measurement indices (snout length, eye diameter, and postorbital length as related to the head length) in lakes Drīdzis, Stirnu, Alūksne and Nirza were compared. The comparison of eye diameter (ED) parameter of vendace revealed that the Lake Alūksnes fish compared to those of Lakes Stirnu, Drīdzis and Nirzas had bigger eye diameter indices, and the Lake Stirnu fish had smaller eye diameter indices than the fish in the other lakes (Table 3). The comparison of StL and PO measurement indices discovered that the vendace in Lakes Alūksnes and Nirzas, had a bigger value of the snout and postorbital length than the fish in lakes Drīdzis and Stirnu.

Comparing morphometric properties in Coregonus albula for the last 50 years (Table 3), we found no significant differences $(P>0.05)$ between our data and the data in Laganovska (1957) and Nikanorov (Никаноров, 1964) for the Lake Nirzas vendace.

As a result of preliminary analysis $(P<0.05)$, considerable distinctions in the body height $(\mathrm{H})$ between males and females aged $3+$ were discovered. No considerable distinctions in other morphological parameters between males and females aged 3+ were found, and therefore, morphological indices of males and females aged $3+$ were added to analysis while the body height parameter $(\mathrm{H})$ was excluded. Most properties liable to age variations are of the exterior kind, and change depends on the speed of fish growth, which is different in various lakes. Dependence of meristic properties on age differs in various fishes.

Table 3

BODY PROPORTIONS OF VENDACE (Coregonus albula) IN THE LATVIAN LAKES AND THE LEVEL OF SIGNIFICANCE OF DIFFERENCES BETWEEN DATA COLLECTED BY LAGANOVSKA (1957), HИKAHOPOB (1964) AND OUR DATA

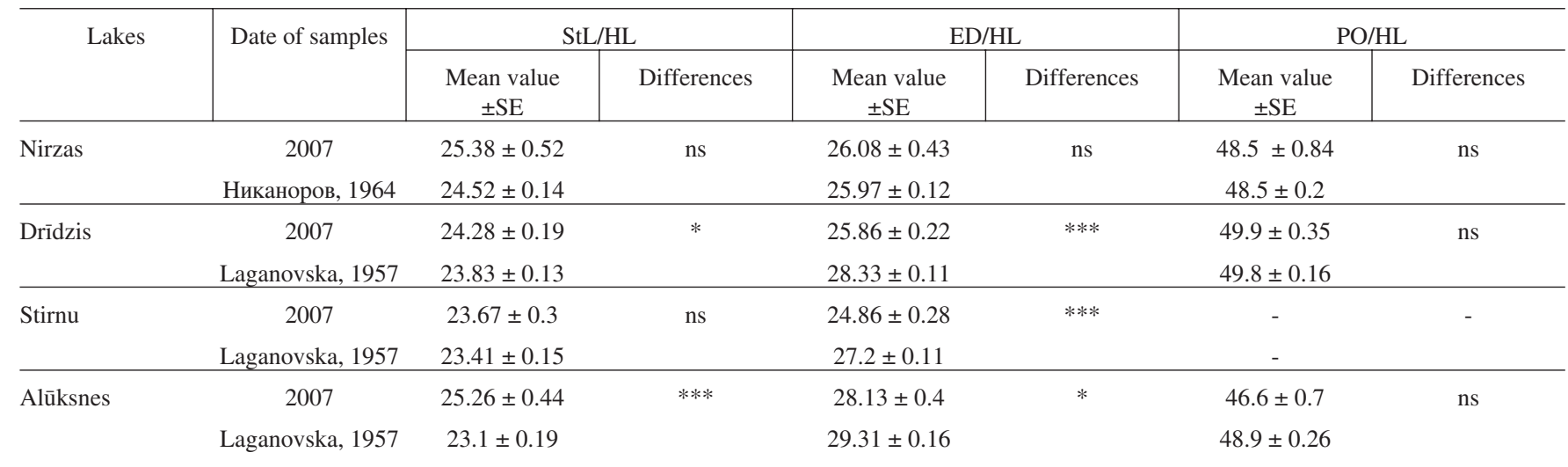

StL, snout length; ED, horizontal diameter of the eye; PO, postorbital length expressed in \% of the head length (HL); ns, not significant differences $(P>0.05)$, * $P<0.05$; ** $P<0.01$; *** $P<0.001$ 
VENDACE CONDITION ACCORDING TO FULTON CONDITION FACTOR IN THE LATVIAN LAKES IN 2007

\begin{tabular}{|c|c|c|c|c|c|c|c|c|c|c|c|c|}
\hline \multirow{2}{*}{ Age } & \multicolumn{2}{|c|}{ Nirza } & \multicolumn{2}{|c|}{ Drīdzis } & \multicolumn{2}{|c|}{ Stirnu } & \multicolumn{2}{|c|}{ Alūksne } & \multicolumn{2}{|c|}{ Svente } & \multicolumn{2}{|c|}{ Rāzna } \\
\hline & $\mathrm{n}$ & $\frac{\underline{\text { Mean }}}{\min -\max }$ & $\mathrm{n}$ & $\begin{array}{c}\stackrel{\text { Mean }}{\min -\max } \\
\end{array}$ & $\mathrm{n}$ & $\underset{\min -\max }{\underline{\text { Mean }}}$ & $\mathrm{n}$ & $\begin{array}{c}\underline{\text { Mean }} \\
\min -\max \end{array}$ & $\mathrm{n}$ & $\begin{array}{c}\underline{\text { Mean }} \\
\min -\max \end{array}$ & $\mathrm{n}$ & $\stackrel{\underline{\text { Mean }}}{\min -\max }$ \\
\hline $2+$ & 1 & 1.09 & - & - & 3 & $\frac{1.10}{1.02-1.18}$ & 44 & $\frac{1.25}{1.03-1.39}$ & 6 & $\frac{1.14}{0.98-1.36}$ & 3 & $\frac{1.30}{1.28-1.33}$ \\
\hline $3+$ & 8 & $\frac{1.23}{1.06-1.43}$ & 42 & $\frac{1.18}{1.07-1.42}$ & 17 & $\frac{1.18}{1.02-1.32}$ & 9 & $\frac{1.27}{1.13-1.38}$ & - & - & 2 & $\frac{1.26}{1.27-1.28}$ \\
\hline $4+$ & 4 & $\frac{1.12}{1.03-1.27}$ & 2 & $\frac{1.16}{1.10-1.21}$ & 6 & $\frac{1.22}{1.16-1.29}$ & - & - & - & - & - & - \\
\hline $5+$ & - & - & - & - & 2 & $\frac{1.22}{1.10-1.34}$ & - & - & - & - & - & - \\
\hline
\end{tabular}

Noticeable differences $(P<0.001)$ in average values of ED were observed in lakes Drīdzis and Stirnu. Eye diameter measurement indices (ED) in the 2007 vendace samples are smaller than this parameter was 50 years ago (Laganovska, 1957).

Fulton's condition factor of the Drīdzis and Stirnu vendace were analysed on the basis of the 2007 data (see Table 4) with the aim of finding out a possible reason for the decrease of the eye diameter index during 50 years (Laganovska, 1957). Vendace of Lakes Drīdzis and Stirnu is currently characterised by a high Fulton's condition factor, which reaches on the average 1.18 with the fluctuation 1.07-1.42 in Drīdzis and 1.02-1.32 in Stirnu (see Table 4).

An increase in snout length and decrease in postorbital length alongside a practically unchanged eye diameter were observed in Lake Alūksnes where vendace is characterised by a poorly developed scale layer and a comparatively small body. A similar body size and structural features were observed in the Lake Rāznas vendace, albeit these features were not as clearly expressed. Fulton's condition factor for vendace in both lakes is rather large, which means that the food reserves in these lakes are sufficient for vendace.

Meristic properties. Meristic properties (RA, LL, sp.br.) over 50 years were compared in lakes Drīdzis, Stirnu, Alūksne, Nirza, Rāznas, and Sventes (Table 5). LL of vendace of Lake Nirzas fish, compared to the fish of lakes Stirnu, Drīdzis, Rāznas, Sventes, and Alūksnes, had a smaller number of scales in the lateral line. Regarding RA, lakes Sventes and Drīdzis vendace had a larger number of rays in the anal fin than the fish in lakes Alūksnes, Rāznas, Nirzas, and Stirnu. The sp.br parameter of vendace revealed that the fish in lakes Nirzas and Drīdzis had a larger number of gill rakers than the fish in other lakes, whereas the Lake Rāznas fish had a smaller number of gill rakers than the fish in the other lakes.

Change of meristic parameters, such features as RA, LL and sp.br., was applied. Like plastic features, they were compared to earlier data (Laganovska, 1957; Никаноров, 1964).

Table 5

MORPHOMETRIC CHARACTERISTICS OF VENDACE IN THE LATVIAN LAKES AND THE LEVEL OF SIGNIFICANCE OF DIFFERENCES BETWEEN DATA COLLECTED BY LAGANOVSKA (1957), HИKAHOPOB (1964) AND OUR DATA

\begin{tabular}{|c|c|c|c|c|c|c|c|}
\hline \multirow[t]{2}{*}{ Lakes } & \multirow[t]{2}{*}{ Date of samples } & \multicolumn{2}{|c|}{ RA } & \multicolumn{2}{|c|}{ LL } & \multicolumn{2}{|c|}{ sp.br. } \\
\hline & & Mean value $\pm \mathrm{SE}$ & Differences & Mean value $\pm \mathrm{SE}$ & Differences & Mean value $\pm \mathrm{SE}$ & Differences \\
\hline \multirow[t]{2}{*}{ Nirzas } & 2007 & $12.92 \pm 0.14$ & $* * *$ & $78.31 \pm 1.11$ & $n s$ & $42 \pm 0.82$ & $n s$ \\
\hline & Никаноров, 1964 & $11.22 \pm 0.04$ & & $80.31 \pm 0.2$ & & $40.8 \pm 0.17$ & \\
\hline \multirow[t]{2}{*}{ Drīdzis } & 2007 & $13.77 \pm 0.12$ & $* * *$ & $87.49 \pm 0.65$ & $n s$ & $40.9 \pm 0.41$ & $* * *$ \\
\hline & Laganovska, 1957 & $11.94 \pm 0.07$ & & $88.1 \pm 0.38$ & & $43.9 \pm 0.23$ & \\
\hline \multirow[t]{2}{*}{ Stirnu } & 2007 & $13.25 \pm 0.12$ & $* * *$ & $85.14 \pm 0.74$ & $n s$ & $38.6 \pm 0.52$ & $* * *$ \\
\hline & Laganovska, 1957 & $11 \pm 0.08$ & & $85.96 \pm 0.43$ & & $42.2 \pm 0.2$ & \\
\hline \multirow[t]{2}{*}{ Sventes } & 2007 & $13.78 \pm 0.22$ & $* * *$ & $90.33 \pm 0.53$ & $n s$ & $39.8 \pm 1.24$ & $* * *$ \\
\hline & Laganovska, 1957 & $12.19 \pm 0.06$ & & $90 \pm 0.33$ & & $44.3 \pm 0.17$ & \\
\hline \multirow[t]{2}{*}{ Rāznas } & 2007 & $13 \pm 0.32$ & $* *$ & $83 \pm 1.02$ & $n s$ & $36 \pm 1.29$ & $* *$ \\
\hline & Laganovska, 1957 & $11.48 \pm 0.09$ & & $83.26 \pm 0.22$ & & $40.9 \pm 0.35$ & \\
\hline \multirow[t]{2}{*}{ Alūksnes } & 2007 & $13 \pm 0.05$ & $* * *$ & $84.89 \pm 0.47$ & $* * *$ & $38.9 \pm 0.37$ & $* * *$ \\
\hline & Laganovska, 1957 & $11.49 \pm 0.07$ & & $86.79 \pm 0.44$ & & $41.9 \pm 0.2$ & \\
\hline
\end{tabular}

RA, number of ray in anal fin; LL, number of scales on the lateral line; sp.br., number of gill rakers; $n s$, not significant differences $(P>0.05$, $* P<0.05$; ** $P<0.01 ; * * * P<0.001)$ 
The obtained results are presented in Table 5. Essential changes in such parameters as RA and sp.br were revealed in all lakes except Nirzas. In the latter, an essential difference in average values is observed only in the parameter RA. The parameter LL demonstrates essential differences only in Lake Alūksnes.

The number of rays in the anal fin increased in all lakes $(P<0.001)$ whereas the number of gill rakers of vendace in all studied lakes decreased $(P<0.001)$ (Table 5).

Cluster analysis. Each population is characterized by a stable set of meristic properties, which allows using them in intraspecific taxonomy. Clustering methods are ways to achieve classification of a series of samples (Krebs, 1999). Romesburg (1984) recommends the UPGMA method for most types of cluster applications, which should increase their ecological insight.

Average linkage between six lakes in Latvia is presented as a dendrogramme in Figures 3 and 4 showing dissimilarity coefficients (Euclidian distances) between investigated populations (Krebs, 1999).

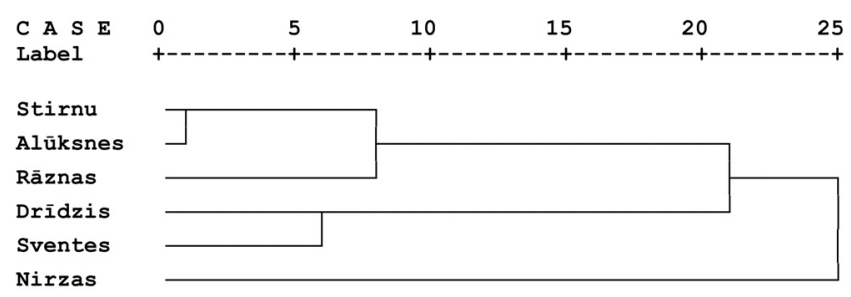

Fig. 3. Average linkage between six vendace populations in investigated Latvian lakes in hierarchical cluster analysis of the variables: RA, LL, and sp.br. (2007 data).

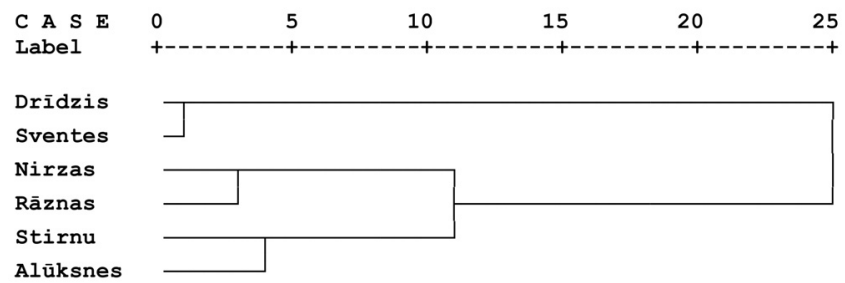

Fig. 4. Average linkage between six vendace populations in investigated Latvian lakes in hierarchical cluster analysis of the variables: RA, LL, and sp.br. Data from Laganovska (1957) and Nikanorov (Никаноров, 1964).

The 2007 data show that vendace populations from lakes Stirnu - Alūksnes and Drīdzis - Sventes are similar. The Lake Nirzas vendace population forms a separate branch. Fifty years ago (Laganovska, 1957; Никаноров, 1964), there was a closer similarity between the populations in lakes Drīdzis and Sventes. Pair-like similarity was also seen between lakes Nirzas - Rāznas and Stirnu - Alūksnes, with populations in lakes Nirzas - Rāznas being most different from those in other lakes. The dendrogramme based on the 2007 data shows that the pair-like similarity of populations in lakes Stirnu - Alūksnes and Drīdzis - Sventes has been retained, although the Euclidean distance between lakes
Stirnu - Alūksnes has decreased. In other words, the vendace populations of lakes Stirnu - Alūksnes have become closer in meristic properties while the vendace populations of lakes Drīdzis - Sventes have become less similar.

The Nirzas vendace changed significantly only in RA (Student's criterion), whereas populations in the other studied lakes demonstrated change in three meristic parameters. Thus, Lake Nirzas population forms a separate branch in cluster analysis.

On the other hand, the Lake Rāznas population has become more similar to the populations of lakes Stirnu and Alūksnes.

\section{DISCUSSION}

Morphological differences in various populations of vendace are mainly determined by ecological reasons, and in most cases these properties are the results of adaptation to living conditions.

A relatively big head and eyes are usual characteristics of slowly growing fish (Решетников, 1980). Average value indices of eye diameter (ED) in 2007 of vendace samples were smaller than 50 years ago (Laganovska, 1957).

Relative eye size can remain large in populations living in conditions of low light (poor transparency of water), which is particularly important for planktonophages (peled, ripus, and vendace) (Потапова, 1978; Решетников, 1980; Anwand, 1997; Czerniejewski and Filipiak, 2002).

One of the possible reasons for decrease of eye measurement indices may be improvement of lake light as a result of increase of a water transparency, or improvement of the lake food reserve. Fish condition increases with improvement of food availability. Considering the high Fulton condition factor, which reaches on average 1.18 with the fluctuation 1.07-1.42 in Drīdzis and 1.02-1.32 in Stirnu (see Table 4), perhaps the food reserve of these lakes was smaller 50 years ago, explaining the larger eye size today. Fulton's condition factor is widely used by many authors in analogical investigations (Романов, 2000; Czerniejewski and Filipiak, 2002; Czerniejewski and Czerniawski, 2004; Czerniejewski et al., 2004). Fulton condition factor varies on the sampling season, nutrition, growth, etc. Polish researchers have proved that Fulton condition factor only slightly changes during the spawning season, 0.05 on the average, in comparison with the feeding season (Czerniejewski et al., 2004).

The vendace from water bodies with a good food reserve are thought to have a short wide head, a snout of a smaller size, and smaller eyes (Бурмакин, 1963). An increase in snout length and decrease in postorbital length alongside a practically unchanged eye diameter was observed in the fish of Lake Alūksnes. The external morphology of Coregonus spp. fishes is known to be determined by living conditions rather than inherited from parents (Решётников, 1980 и 
др.). Some authors have noted a radical change of external features as a result of acclimatization in new water bodies, particularly in head size (Бурмакин, 1963; Решётников, 1980).

Introduction of vendace in Latvia took place in the beginning and middle of the last century (Никаноров и Никанорова, 1956). Data related to the current populations of vendace in Latvian lakes can provide information about vendace adaptation and morphometric features may show changes after their introduction.

Individuals in Lake Alūksnes (Table 3) had increased growth rate shown by larger fish length accompanied by decrease of eye measurement indices. Our data show, however, that mean fish weight and length have not increased in the last 50 years; on the contrary, there has been a decrease of the vendace size in the Lake Alüksnes (Laganovska, 1957; Никаноров, 1964), which can be interpreted as a result of its adaptation to the lake conditions.

Lake Alūksnes does not have an optimal habitat for vendace, which can be noticed without any preliminary measurements. A poorly developed scale layer and a comparatively small body characterise the Lake Alūksnes vendace. Similar body size and structure features are observed in the Lake Rāznas vendace albeit these features are not so clearly expressed. Some authors have observed that in comparatively small and shallow water bodies, fins, scales layer, and carcass of vendace are less developed (Бурмакин, 1963; Суховерхов, 1975).

Thus, a poorly developed scale layer and comparatively small body of vendace are less expressed in Lake Rāznas, which is as deep as the Lake Alūksnes but is much larger in size. The Fulton's condition factor for vendace is large enough in both lakes, which means that the food reserves in these lakes are quite sufficient for vendace. Our data indicate a considerable impact of the factor "lake" on vendace morphology in the Lake Alūksnes.

Meristic features are less changeable under the influence of environment, and thus are used for establishing systematic position of lower taxonomic units.

It is also known that variation in fish is particularly strongly influenced by temperature (Бурмакин, 1963), which can affect a number of rays in unpaired fins, gill rakers, and scales in the side (lateral) line. In other words, in the lakes where the incubation temperature on the spawning grounds is lower, the above mentioned parameters increase in number. As mentioned above, the number of rays in the anal fin increased in all investigated lakes, while the number of gill rakers decreased (see Table 5).

Some authors believe that alongside temperature the quality of food reserve influences variation in the number of gill rakers. Никаноров (1964), for example, points out that vendace has more gill rakers in water bodies with poorer food reserves. According to other researchers, vendace has a smaller number of gill rakers in lakes where it consumes larger zooplankton organisms (Решетников, 1980). Our data show that the food reserves in the studied lakes have considerably improved in the last 50 years, which has led to a smaller number of gill rakers in vendace (Fig. 5).

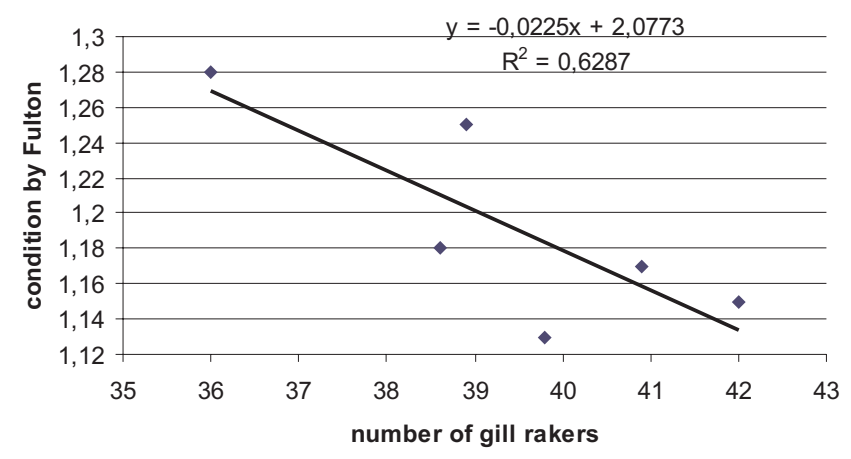

Fig. 5. Relation between mean of gill raker number and fish condition (according to Fulton condition factor) of vendace in six Latvian lakes

Thus, the change of meristic characteristics can be considered as a result of adaptation of local vendace populations to the changing conditions of Latvian lakes during the last 50 years.

Unlike plastic features, calculable ones are less viable to change. The number of gill rakers has been used for distinguishing species and intraspecific forms of the Coregonus fishes. Each population is characterised by a stable set of meristic properties, which allows using them for intraspecific taxonomy. However, meristic properties can be used in intrataxonomic and population research if fish samples contain individuals of various ages, and are sufficiently big. In this case possible slight fluctuations of average values in individuals of different generations are evened out (Решетников, 1980).

Judging by meristic properties, the Lake Rāznas vendace population has become more similar to the populations of lakes Stirnu and Alūksnes.

Nikanorov (Никаноров, 1964) noted that the lakes Nirzas and Sventes populations of vendace had considerable distinctions in meristic properties, which is clearly seen in the dendrogramme (see Figure 4). He further mentioned considerable variation in meristic properties in the Lake Drīdzis vendace and argued that this can be accounted for by a complex bottom relief of this lake, a large amount of bays, and location of the vendace spawning grounds in places at varying depths, which creates different conditions for growth and development of vendace.

In lakes Nirzas and Rāznas the living conditions are more homogeneous, lake properties are less variable, spawning grounds are concentrated in one place; a simple relief provides homogeneous and quite stable conditions for development and life. Thus, the variability of vendace properties in these lakes would be expected to be considerably less expressed than in the vendace of the Lake Drīdzis. On the contrary, the lakes with more homogeneous living condi- 
tions in our studies sometimes revealed more considerable variation of properties.

This fact can be accounted for by the following. Firstly, in 2007, samples were collected during the spawning period, hence they consisted of individuals of the same spawning population. Secondly, living conditions in deep lakes can be considered as stable as they are characterised by clear temperature stratification in summer, and vendace can easily move to deeper waters with a low temperature, which is a known feature of the Coregonidae fish. At the present stage of research, it does not appear possible to establish major factors that have contributed to the change of morphometric indices in fish for the last 50 years. Various factors may demonstrate different effects on the organism in various lakes, which also influences the degree of variation of properties.

The diversity and variation of morphological characteristics of vendace in the studied lakes was within the range of variations of the European vendace (Coregonus albula (L.), although the variation was lake-specific and depended on the local conditions of each reservoir. The discovered changes in the vendace populations from Lakes Nirzas, Rāznas, Stirnu, Alūksnes, Drīdzis, and Sventes seem to have resulted solely due to the adaptation of vendace to living conditions, which changed during the previous 50 years.

\section{ACKNOWLEDGEMENTS}

This study was supported by the ESF project Nr. VPDI/ ESF/PIAA/04/NP/3.2.3.1/0003/0065.

Collection of the material was accomplished with the help of the Latvian Fish Resources Agency specialists' Eriks Aleksejevs, Arkādijs Poppels, and Jānis Aizups.

We are grateful to Professor Artūrs Škute, Dr. biol., for methodological help in statistical analysis of data and critically reading the manuscript. We are grateful to the reviewer of the paper for critical questions and comments on our manuscript.

\section{REFERENCES}

Anwand, K., Staaks, G., Valentin, M. (1997). Zwei unterschiedliche Formen von Coregonus albula (Teleostei; Coregonidae) im nordbrandenburgischen Stechlinsee (Deutschland). Z. Fisch, Solingen, 4(1-2), 3-14.

Arhipova, I., Bāliņa, S. (2003). Statistika ekonomikā. Risinājumi ar SPSS un Microsoft Excel [Statistics in economics. Calculation by SPSS and Microsoft Excel]. Rīga: Datorzinību centrs, 135.-139. 1pp. (in Latvian).

Czerniejewski, P., Czerniawski, R. (2004). Age, growth and condition of vendace Coregonus albula (L.) from lakes Morzyczko and Pelcz (NW Poland). Zoologica Poloniae, 49(1-4), 159-170.

Czerniejewski, P., Filipiak, J. (2002). Biological and morphological characteristics of vendace, Coregonus albula L. from lakes Drawsko and Pełcz. Acta Ichthyol. Piscat., 32(1), 53-69.

Czerniejewski, P., Filipiak, J., Poleszczuk, G., Wawrzyniak, W. (2004). Selected biological characteristics of the catchavailable part of the population of vendace, Coregonus albula (L.) from lake Miedwie, Poland. Acta Ichthyol. Piscat., 34(2), 219-233.
Kaupinis, A., Bukelskis, E. (2004). Vendace (Coregonus albula (L.)) growth and morphological diversity in lakes of Lithuania. Acta Zoologica Lituanica, 14(1), 3-12.

Krebs, C.J. (1999). Ecological Methodology. Menlo Park, CA: Addison Wesley Longman, Inc. 620 pp.

Laganovska, R. (1957). Latvijas PSR ezeru repsis - Coregonus albula un tā biologija LPSR [European vendace - Coregonus albula in the lakes of Latvian Soviet Socialist Republic and its biology in LSSR]. LPSR ZA Vēstis Nr. 3(116), 83.-96. 1pp. (in Latvian).

Lajus, D.L. (2001). Variation patterns of bilateral characters: Variation among characters and among populations in the White Sea herring (Clupea palasi marisalbi). Biol. J. Linn. Soc., 74, 237-253.

Lajus, D.L., Knust, R., Brix, O. (2003). Fluctuating asymmetry and other parameters of morphological variation of eelpout Zoarces viviparus from different parts of distributional range. Sarsia, 88, 247-260.

Lowe, A., Harris, S., Ashton, P. (2004). Ecological genetics. Oxford: Blackwell Publishing. 326 pp. (at pp. 15-20).

Plikšs, M., Aleksejevs, Ē. (1998) Zivis [Fish]. Rīga: Gandrs. 80.-81. 1pp. (in Latvian).

Romesburg, H.C. (2004). Cluster Analysis for Researchers. Morrisville, NC: Lulu Press, Inc. 344 pp.

Бурмакин Е.В. (1963). Акклиматизация пресноводных рыб в СССР [Acclimatization of freshwater fishes in USSR]. Известия государственного научно-исследовательского института озерного и речного рыбного хозяйства, Т. LIII, 314 с. (in Russian).

Гуричев П.А., Белоусов И.Ю. (2005). Внутривидовая дифференциация сига губы Кереть Белого моря и прилежащих озер [Intraspecific differentiation of the whitefish in the White Sea Bay of Keret and adjacent lakes]. Материаль IX международной конференции: Проблемы изучения, рационального использования и охраны ресурсов Белого моря, с. 87-91 (in Russian).

Лакин Г.Ф. (1980). Биометрия [Biometrics]. Высшая школа, Москва. C. 97-100 (in Russian).

Никаноров Ю.И. (1964). Морфологические особенности локальных стад европейской ряпушки Coregonus albula в зависимости от условий обитания [Morphological peculiarities of the local populations of European vendace Coregonus albula subject to living conditions]. Bonpcbl ихтиологии, 4. Вып. 3(32), с. 411-422 (in Russian).

Никаноров Ю.И., Никанорова Е.А. (1956) Искусственное разведение ряпушки в Латвийской ССР [Artificial breeding of vendace in Latvian SSR]. Научно-технический бюллетень ВНИОРХ, № 3-4, с. 58-61 (in Russian).

Перескоков А.В., Рогозин А.Г. (2001). Некоторые особенности чудского сига из озера Большое Миассово [Some peculiarities of the Choud whitefish from the Lake Bolshoje Miassovo]. Известия Челябинского научного центра, 4(13), с. 68-72 (in Russian).

Потапова О.И. (1978). Крупная ряпушка Coregonus albula (L.) [Big Vendace Coregonus albula (L.)]. Ленинград: Наука. 132 c. (in Russian).

Правдин И.Ф. (1966). Руководство по изучению рыб [A Guide to Fish Studies]. Москва: Пищевая промышленность. 375 с. (in Russian).

Решетников Ю.С. (1980). Экология и систематика сиговых рыб [Ecology and Systematics of Coregonids]. Москва: Наука. 300 с. (in Russian).

Романов В.И. (2000). Морфоэкологическая характеристика ряпушки из оз. Томмот (бассейн р. Хатанги) и некоторые дискуссионные вопросы систематики евразийских ряпушек [Morphoecological characteristics of coregonus from the Lake Tommot (River Khatanga Basin) and some disputable questions of European coregonus systematics]. Сибирский экологический журнал, 3, 293-303 (in Russian).

Суховерхов Ф.М., Сиверцов, А.П. (1975). Прудовое рыбоводство [Fish Breeding in Ponds]. Москва, Пищевая промышленность. 311 с. (in Russian). 
VIETĒJO EIROPAS REPŠA (Coregonus albula (L.)) POPULĀCIJU MORFOLOG̦ISKAIS RAKSTUROJUMS DAŽOS LATVIJAS EZEROS PĒDĒJO 50 GADU LAIKĀ

Eiropas repsis (Coregonus albula) ir plaši izplatīta suga Holarktikas ūdeņos. Repsis tiek uzskatīts kā komplekss objekts izplatīšanās vēstures un evolūcijas izpētei. Darbā tika veikta morfometrisko un meristisko parametru izmaiņu statistiskā analīze. Tika novērotas sešu Latvijas ezeru repšu populācijas pēdējo 50 gadu laikā. Klasteranalīze parādīja, ka Stirnu un Alūksnes ezeru repša populācijas pēc meristiskiem parametriem kḷuva tuvākas, bet atškirība starp Drīdža un Sventes ezeru repšiem ar laiku kḷuva izteiktāka. Aprakstītie Latvijas repši pieder Coregonus albula (L.) sugai, jo visumā pēc morfoloǵiskajām pazīmēm tie ir līdzīgi šīs sugas pārstāvjiem. Katrā ezerā dzīvo pēc morfolog̣iskām pazīmēm atškirīga vietējā repšu populācija, repšu forma, kura vairāk piemērojusies vietējiem apstākḷiem un izveidojusies to ietekmē. Aprakstītās izmaiņas Nirzas, Rāznas, Stirnu, Alūksnes, Drīdža un Sventes repšu populācijās var pieņemt par aklimatizācijas rezultātu, t.i., repša pielāgošanās rezultātu vietējiem vides apstākḷiem, kas mainījušies pēdējo 50 gadu laikā. 